\title{
Tectonic control on the stratigraphic framework of Late Pleistocene and Holocene deposits in Marajó Island, State of Pará, eastern Amazonia
}

\author{
DILCE F. ROSSETTI
}

Instituto Nacional de Pesquisas Espaciais - INPE, Observação da Terra-Divisão de Sensoriamento Remoto (OBT/DSR), Rua dos Astronautas, 1758, Caixa Postal 515, Jardim da Granja, 12245-970 São José dos Campos, SP, Brasil

Manuscript received on November 17, 2008; accepted for publication on March 26, 2009

\begin{abstract}
The traditional view that the Brazilian Amazonia is located in a tectonically stable area since the Cretaceous is changing in front of the increasing documentation of fault reactivations even during the Holocene. How the sedimentary record has responded to these events is an issue that remains to be approached with basis on field data. This work focuses on the stratigraphic correlation of late Quaternary deposits from eastern Marajó Island, with the goal of demonstrating the role of fault reactivation on the origin and preservation of these deposits. Despite the location in a stable platform of a continental passive margin, three studied stratigraphic units display significant vertical offsets that define two depocenters that are better explained through tectonic displacements. This interpretation is reinforced by several morphostructural features related to faults that occur between the studied drills. Without the influence of tectonics, sediment preservation in this characteristically low-lying terrain would have been negligible. The results of the present work motivate to look for other tectonically-influenced areas in Amazonia, which similarly might have acted as sites for sediment accommodation during the late Quaternary. These sedimentary records have great potential to be the source of valuable information for reconstructing Quaternary geological events in Northern Brazil.
\end{abstract}

Key words: Amazonia, tectonics, Quaternary, stratigraphic framework, radiocarbon dating, sedimentation.

\section{INTRODUCTION}

Marajó Island is a flat-lying area of very low relief positioned almost at the modern sea level. Its western side is located in the Limoeiro Sub-basin. This is the central depression of the Marajó Graben System, a structure that resulted from reactivation of normal and strike-slip faults related to the opening of the Equatorial South Atlantic Ocean (Azevedo 1991, J.M.C. Villegas, unpublished data, Costa and Hasui 1997). Faults remained active in this area through the Cenozoic, with some motion occurring even during the Holocene (J.M.C. Villegas, unpublished data). In contrast to the tectonically active nature of western Marajó, its eastern side, inserted in the Pará Platform, has been traditionally regarded as an area of great stability. This feature corresponds to

E-mail: rossetti@dsr.inpe.br a large, shallow area of crystalline and Paleozoic sedimentary rocks that remained tectonically stable relative to adjacent Cretaceous and Cenozoic sedimentary basins.

A previous work has claimed that the Pará Platform is probably not tectonically stable as primarily envisaged (Azevedo 1991). According to this author, the apparent stability of this area reflects a lack of detailed studies, which have precluded the recognition of small tectonically subsiding sedimentary basins. In fact, a Bouguer gravity map indicates a negative anomaly paralleling a large north-south oriented lake, i.e., the Lake Arari, in northeastern Marajó Island, which is suggestive of a basin connected to the offshore Mexiana Sub-basin of the Marajó Graben System (Rossetti et al. 2008a). Additionally, these authors have presented a study integrating mapping of geomorphological lineaments with analysis 
of soft sediment deformation structures related to seismic activity in support of fault displacement in eastern Marajó. Interestingly, some of these faults have caused many segmentation of geomorphological features related to Late Pleistocene to Holocene paleochannels (Rossetti and Valeriano 2007, Rossetti et al. 2007, 2008b), attesting that fault motion took place very recently in this area. Seismographic records revealing earthquakes as large as magnitude 4.8 in eastern Marajó (Miotto 1993) also sustain this interpretation.

Despite the available evidence for tectonic activity in eastern Marajó Island, further investigation is still needed in order to provide a widespread documentation concerning to the influence of fault activity on sediment deposition during the Quaternary of this area. In particular, the faults must be mapped in sub-surface. Unfortunately, subsurface data, particularly considering seismic lines, are not available for study.

The present work has the main goal of furnishing the stratigraphic framework of late Quaternary deposits of eastern Marajó Island (Fig. 1A) based on core data obtained along a nearly $170 \mathrm{~km}$-long transect (Fig. 1B). The lateral distribution of sedimentary units along this section, combined with radiocarbon ages and morphostructural information derived from remote sensing interpretation, helped to demonstrate that fault reactivation is an important process controlling the sediment piling in this flat-lying area of Northern Brazil.

\section{GEOLOGICAL CONTEXT}

The Pará Platform, located in the northeast of the State of Pará, Northern Brazil, is bounded by the Vigia-Castanhal trough to the east, Mexiana Sub-Basin to the north, Limoeiro Sub-basin to the southwest, and Cametá Subbasin to the southeast (Fig. 1A). The three latter basins are part of the Marajó Graben System, while the VigiaCastanhal trough represents an offshore extension of the Cametá Sub-basin.

The Marajó Graben System encompasses an area of $1.5 \times 106 \mathrm{~km}^{2}$, and consists of a NW-SE, and then a NE-SW, oriented rift. This structure is defined mostly by NW-SE and NE-SW normal faults reactivated from the Precambrian basement, but E-W to ENE-WSW and NE-SW strike-slip faults have also been recorded (Azevedo 1991, Costa and Hasui 1997, Fig. 1A). The rift ex- perienced two extensional phases. The first one is related to the opening of the Equatorial South Atlantic Ocean in the late Jurassic and early Cretaceous (Szatmari et al. 1987), but a second, and more important, extensional episode took place in the Aptian-Albian transition. In addition, seismic data from all sub-basins of the Marajó Graben System show indications of fault reactivation along strike slip zones throughout the Cenozoic (J.M.C. Villegas, unpublished data).

The sedimentary fill of the Marajó rift basins (Fig. 2 ), mostly based on subsurface data, consists of Cretaceous to Quaternary fluvial to nearshore deposits (J.M.C. Villegas, unpublished data). Sandstone of the Breves/ Jacarezinho Formations (Aptian-Cenomanian), and silty mudstones of the Anajás Formation (Cenomanian) are overlain by sandstones, mudstones and conglomerates of the Upper Cretaceous to Paleocene Limoeiro Formation. Other Tertiary deposits consist of mixed siliciclastic limestones of the Marajó Formation (PaleocenePliocene), as well as sandstones and mudstones of the Tucunaré and Pirarucu Formations of the Pará Group (Quaternary). The latter includes the studied Quaternary deposits in eastern Marajó Island.

\section{METHODS}

The characterization of the sedimentary units provided herein was based on descriptions of sediments from cores collected on 13 shallow drills and 2 trenches (MOC-F and TR-1) distributed along an $170 \mathrm{~km}$-long transect in eastern Marajó Island. The cores were collected using a RKS percussion drilling system, model COBRA mk1, with one core obtained using a rotating drilling system. The first method allowed the sampling of cores with $4.5 \mathrm{~cm}$ in diameter up to a depth of $25 \mathrm{~m}$, while the second system provided a continuous core of $6.0 \mathrm{~cm}$ in diameter up to $120 \mathrm{~m}$ depth. The sedimentary facies were properly recorded in lithostratigraphic profiles. Although detailed facies descriptions aiming the reconstruction of depositional settings were performed, the result of this study will be presented elsewhere, because the focus of this work is the regional stratigraphic correlation. Therefore, the sedimentary facies will be only briefly described in order to characterize the studied stratigraphic units. Facies descriptions were combined with the mapping of 

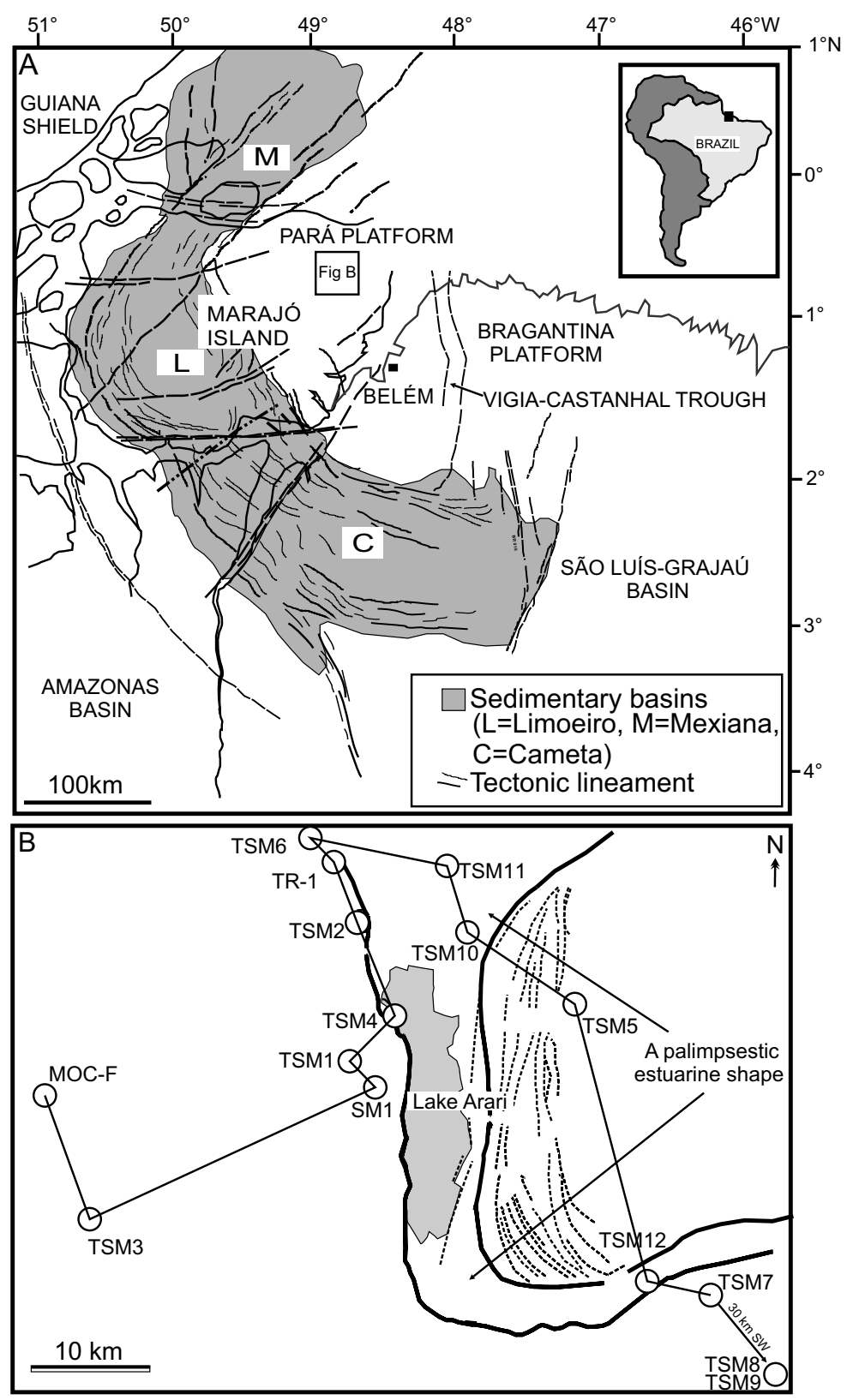

Fig. 1 - A) Location of the study area in northeastern Marajó Island, Pará Platform, Northern Brazil. B) Location of the studied drills in Lake Arari area, with indication of a morphological feature related to the paleoestuary discussed in the text.

discontinuity surfaces that could be significant for stratigraphic correlation.

The chronology was based on 39 radiocarbon analyses undertaken at the Beta Analytic Radiocarbon Dating Laboratory and at the AMS-Labor Erlangen. Samples of peat, wood, and organic sediments were dated using the Accelerator Mass Spectrometer (AMS). The sam- ples were pre-treated with acid to remove carbonates and weaken organic bonds, washed with alkali to remove secondary organic acids, and then combined with acid again to provide more accurate dating. Conventional ${ }^{14} \mathrm{C}$ ages were calibrated to calendar years according to Talma and Vogel (1993) and McCormac et al. (2004).

Additionally, a description of morphostructural fea- 


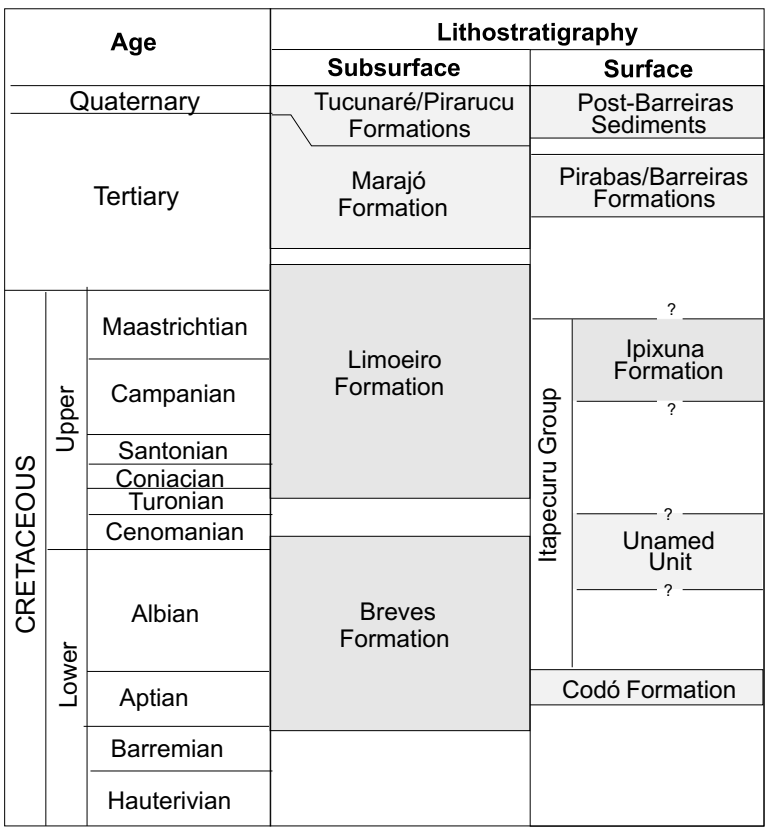

Fig. 2 - Simplified litostratigraphic chart representative of the sedimentary sub-basins in the Marajó Graben System.

tures based on remote sensing analysis was performed in selected areas in order to discuss the fault interpretation provided in the geological section. This procedure was based on Landsat 5-TM (Ref. 224-060 and 225-061 from INPE, the Brazilian National Institute for Space Research) and Landsat 7-ETM (Ref. 223-060 and 223061, GLCF) images, collected on August 2001. Topography derives from data collected by the Shuttle Radar Topography Mission (SRTM-90 m), freely distributed by the National Aeronautics and Space Administration NASA.

\section{DESCRIPTION OF SEDIMENTARY UNITS}

Integration of core information with radiocarbon dating provided the basis for establishing the stratigraphic framework for the latest Quaternary sedimentation of eastern Marajó Island (Fig. 3). Three broad stratigraphic units were recognized, named herein as units 1,2 and 3. These are composed by fluvial, lacustrine and estuarine deposits ranging from mud to coarse-grained sands that commonly display variable volumes of plant debris (Rossetti and Valeriano 2007, Rossetti et al. 2007). Analysis of the lateral distribution of these units throughout the study area revealed significant thickness variations for individual units. In general, two depocenters, characterized by an overall increased thickness of the sedimentary units, are present, one at SM-1 and the other one at TSM-10. The first is the deepest one, located at $120 \mathrm{~m}$ depth and circa $100 \mathrm{~m}$ below the depocenter at drill TSM-10. The geological section presented in Figure 3 depicts several interpreted faults that better accommodate both the great differences in bed thickness and the lateral distribution of radiocarbon ages. After descriptions of individual sedimentary units, provided below, a following section will discuss the fault interpretation suggested in this figure.

Unit 1 occurs at the base of the drills. Its base could not be observed in the cores, but it reaches almost $90 \mathrm{~m}$ in drill SM-1. The top of this unit is very irregular, being located at $33 \mathrm{~m}$ depth at the main depocenter, while away from this area it can be at the surface (drill TSM7). The two drills located at the western and eastern extremities of the studied transects display the top of Unit 1 as shallow as 2 and $1 \mathrm{~m}$, respectively. This unit is lacking in the drills TSM-5, TSM-11 and TSM-12. Unit 1 consists of sandy packages that are up to $35 \mathrm{~m}$ thick and often organized into numerous fining upward cycles. The sands are massive, cross-stratified, parallellaminated or display several soft sediment deformation structures, mostly including convolute folds and microfaults (see Rossetti et al. 2008a for a detailed description of these deformation structures). The sandy strata are interbedded with packages up to $10 \mathrm{~m}$ thick consisting of muds and heterolithic deposits that are frequently organized into coarsening upward cycles. The irregular top surface characterizes a discontinuity surface that, in shallow depths, overlies highly weathered deposits consisting of a massive, homogenous, endured and often ferruginous nature. Noteworthy is that these strata, which may reach up to $2 \mathrm{~m}$ thick, grade downward into deposits displaying primary sedimentary structures. Radiocarbon ages obtained from Unit 1 range between 55,082 $( \pm 12,354){ }^{14} \mathrm{C}$ yr B.P. and $16,118( \pm 80){ }^{14} \mathrm{C}$ yr B.P. (Table I).

The intermediate Unit 2 displays thickness variation between 2 and $22 \mathrm{~m}$, as observed in the drills MOC-F and SM-1, respectively. Although considerably less irregular than its base, the top of this unit is also marked by a sharp discontinuity surface. This is located at a greatest 


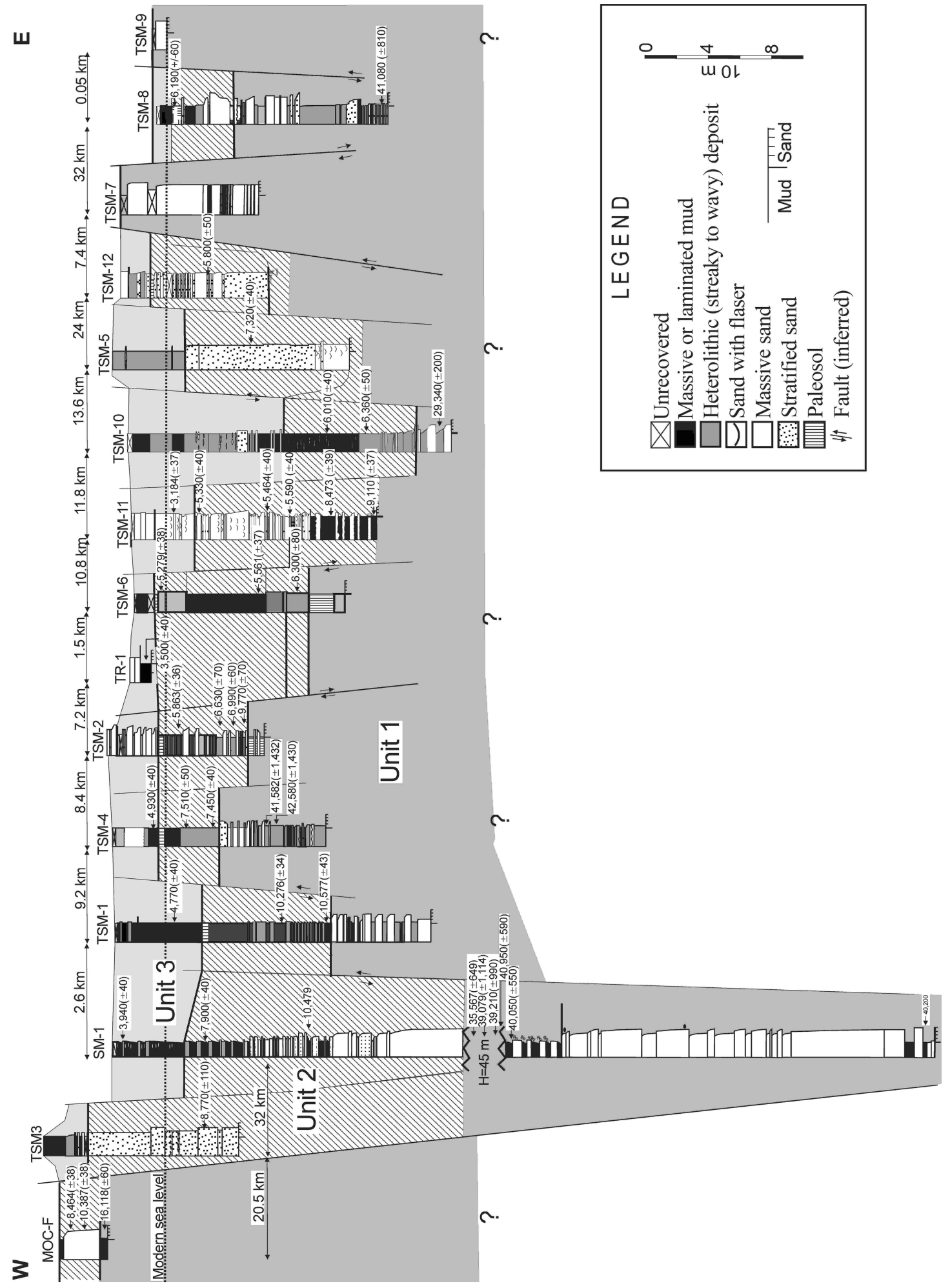

Fig. 3 - Lithostratigraphic profiles used in this study, with the interpreted stratigraphic framework established for the latest Quaternary sedimentation. Faults among drills were included in this section for illustrative purposes, as they might actually correspond to a fault zone. See text for further discussion concerning to the presence of these faults in the study area. 
depth in the drill SM-1, where it occurs $33 \mathrm{~m}$ below the modern surface; the drill MOC-F displays Unit 2 at the surface. In general, there is an overall thickness decrease toward the edges of the studied transect. The deposits are lithologically similar to Unit 1, consisting of fining upward sand packages that either are interbedded or grade upward into muddy strata. However, there are several places where either sand beds (MOC-F, TSM3, TSM-7, TSM-5, TSM-13) or mud beds (TSM-1, TSM-4, TSM-6, TSM-10) dominate. Deposits underlying the top discontinuity surface also have evidence of weathering, being characterized by mottled sands and muds with red and dark yellow colors due to iron staining. The thickness of the weathered deposits, however, is much less than (i.e., only few centimeters thick) in similar deposits observed at the top of Unit 1. Unit 2 records only early to middle Holocene ages, indicated by radiocarbon dates ranging from $10,577( \pm 43){ }^{14} \mathrm{C}$ yr B.P. to $5,279( \pm 38){ }^{14} \mathrm{C}$ yr. B.P. (Table I).

The uppermost Unit 3 is, in general, thinner relative to the other ones, with a maximum thickness of $11.5 \mathrm{~m}$, as verified in the drill TSM-10. Away from this area, this Unit becomes thinner, being completely absent in some drills located in the western and eastern extremities of the studied transect (i.e., drills MOC-F, TSM7 and TSM-9). Due to the proximity to the surface, the deposits are often weathered and mottled in yellow and reddish. Sandy deposits dominate in the drills TSM2, TSM-7, TSM-11, TSM-12, while in the others the prevailing lithologies are muds and heterolithic deposits. Radiocarbon dating recorded ages younger than the middle/early Holocene, ranging from 4,770 $( \pm 40){ }^{14} \mathrm{C}$ yr B.P. to $3,184( \pm 37){ }^{14} \mathrm{C}$ yr B.P. (Table I).

\section{MORPHOSTRUCTURAL CHARACTERIZATION}

Analysis of the processed Landsat image reveals several morphostructural lineaments defined by straight drainage segments that are suggestive of fault activity along the areas located among the studied drills. The goal of this section is not to present an extensive description of the morphostructural context for the study area. The focus will be on selected areas among and around the studied drills in order to support the existence of tectonic faults suggested by the stratigraphic correlation shown in Figure 3.
The first area to be described is the one between the drills TSM-6 and TSM-11. This area is at the mouth of a large palimpsestic feature related to a paleoestuary that, once abandoned, gave rise to Lake Arari (Rossetti et al. 2007, Fig. 1B). Drills TSM-6 and TSM-11 are located at the left margin and in the center of this estuary (Fig. 4A,B), respectively. The paleoestuary margin is straight, and a previous work has shown its relation to tectonic faults (Rossetti et al. 2008a). Additionally, the drainage system between these drills, as well as from their adjacencies, is complex, being characterized by an abundance of straight channels that not rarely bifurcate at high angles of, or close to, $90^{\circ}$. Main, NE-SW oriented straight channels parallel to each other cut across the entire area, reaching the paleoestuary margin. Noteworthy are the drainage anomaly consisting of straight channels that become highly meandering, and the tributary channel that is linked to the main stream through a segment of channel much narrower than its average width (Fig. 4B). The prevailing drainage pattern can be classified as angular, with local development of trellis. Furthermore, it is interesting to notice the segments of paleochannels with sharply based edges, defined by the interception of straight modern channels.

The second area relevant to this study locates between the drills TSM-11 and TSM-10, the latter positioned at the center of the paleoestuary, circa $12 \mathrm{~km}$ south of drill TSM-11 (Fig. 4B). Likewise the area described above, this one is also characterized by straight channels connected at angles of $90^{\circ}$ which define the prevalence of an angular drainage pattern. However, the most striking feature in this sector is a northward and a southward drainage basin separated by an area crossed by two straight parallel channels showing an E/NE-W/SW orientation. Despite the overall very low topography, digital elevation data suggest slightly higher altitudinal values in this place (see the topographic profile in the lower part of Fig. 4B).

The third area to be described herein is located between drills TSM-10 and TSM5. This area (Fig. 4C) is interesting, because it crosses over the eastern margin of the paleoestuary. The margin is very straight at this place. A topographic profile derived from digital elevation data between these drills revealed areas of relatively lower and higher topography to the west and east 
TABLE I

Radiocarbon ages for samples collected from the three stratigraphic units of the study area.

\begin{tabular}{|c|c|c|c|c|}
\hline $\begin{array}{l}\text { STRAT. } \\
\text { UNIT }\end{array}$ & Drill & Type of Material & ${ }^{14}$ C yr B.P. & $\begin{array}{c}\text { Cal year B.P. 2-sigma } \\
\text { calibration (type of analysis) }\end{array}$ \\
\hline \multirow{11}{*}{1} & MOC-F & organic sediment & $16,118(+/-80)$ & (AMS) \\
\hline & & organic sediment & $35,587(+/-649)$ & (AMS) \\
\hline & & organic sediment & $39,079(+/-1,114)$ & (AMS) \\
\hline & & organic sediment & $39,210(+/-990)$ & (AMS) \\
\hline & & organic sediment & $40,050(+/-550)$ & (AMS) \\
\hline & & organic sediment & $40,950(+/-590)$ & (AMS) \\
\hline & & organic sediment & 40,200 & (AMS) \\
\hline & \multirow[t]{2}{*}{ TSM4 } & organic sediment & $41,582(+/-1,432)$ & (AMS) \\
\hline & & organic sediment & $42,580(+/-1,430)$ & (AMS) \\
\hline & TSM8 & organic sediment & $41,080(+/-810)$ & (AMS) \\
\hline & TSM10 & organic sediment & $29,340(+/-200)$ & (AMS) \\
\hline \multirow{24}{*}{2} & \multirow[t]{2}{*}{ MOC-F } & organic sediment & $8,464(+/-38)$ & (AMS) \\
\hline & & organic sediment & $10,387(+/-38)$ & 7,575-7,447 (AMS) \\
\hline & \multirow[t]{2}{*}{ SM1 } & organic sediment & $7,900(+/-40)$ & 8,800 to 8,600 (AMS) \\
\hline & & organic sediment & 10,479 & (AMS) \\
\hline & \multirow[t]{2}{*}{ TSM1 } & organic sediment & $10,577(+/-43)$ & (AMS) \\
\hline & & organic sediment & $10,276(+/-34)$ & (AMS) \\
\hline & \multirow[t]{3}{*}{ TSM2 } & peat & $6,630(+/-70)$ & 7,610 to 7,420 (radiometric) \\
\hline & & peat & $6,990(+/-80)$ & 7,940 to 7,680 (AMS) \\
\hline & & peat & $9,770(+/-70)$ & $11,250-11,100$ (AMS) \\
\hline & TSM3 & peat & $8,850(+/-110)$ & $10,220-9,550$ (radiometric) \\
\hline & \multirow[t]{2}{*}{ TSM4 } & organic sediment & $7,450(+/-40)$ & 8,360 to 8,180 (AMS) \\
\hline & & organic sediment & $7,510(+/-50)$ & 8,400 to $8,200(\mathrm{AMS})$ \\
\hline & \multirow[t]{3}{*}{ TSM6 } & organic sediment & $5,279(+/-38)$ & 6,031-5,909 (AMS) \\
\hline & & organic sediment & $5,561(+/-37)$ & $6,402-6,270(\mathrm{AMS})$ \\
\hline & & peat & $6,300(+/-80)$ & $7,410-7,000$ (radiometric) \\
\hline & TSM8 & peat & $6,190(+/-60)$ & $7,250-6,900$ (radiometric) \\
\hline & \multirow[t]{3}{*}{ TSM10 } & organic sediment & $6,010(+/-40)$ & 6,950 to $6,740(\mathrm{AMS})$ \\
\hline & & organic sediment & $6,360(+/-50$ & 7,420 to 7,170 (AMS) \\
\hline & & organic sediment & $5,330(+/-40)$ & 6,210 to $5,990(\mathrm{AMS})$ \\
\hline & \multirow[t]{4}{*}{ TSM11 } & organic sediment & $5,464(+/-40)$ & 4,349-4225 (AMS) \\
\hline & & organic sediment & $5,590(+/-40)$ & 6,440 to 6,300 (AMS) \\
\hline & & organic sediment & $8,473(+/-39)$ & 7,579-7,448 (AMS) \\
\hline & & organic sediment & $9,110(+/-37)$ & $8,320-8,222$ (AMS) \\
\hline & TSM12 & organic sediment & $5,800(+/-50)$ & 6,730 to $6,480(\mathrm{AMS})$ \\
\hline \multirow{4}{*}{3} & SM1 & organic sediment & $3,940(+/-40)$ & $4,510-4,470$ (AMS) \\
\hline & \multirow[t]{2}{*}{ TSM1 } & wood & $4,770(+/-40)$ & 5,380 to $5,340(\mathrm{AMS})$ \\
\hline & & wood & $4,791(+/-33)$ & 3,636-3,497 (AMS) \\
\hline & TSM4 & organic sediment & $4,930(+/-40)$ & $5,740-5,600(\mathrm{AMS})$ \\
\hline
\end{tabular}



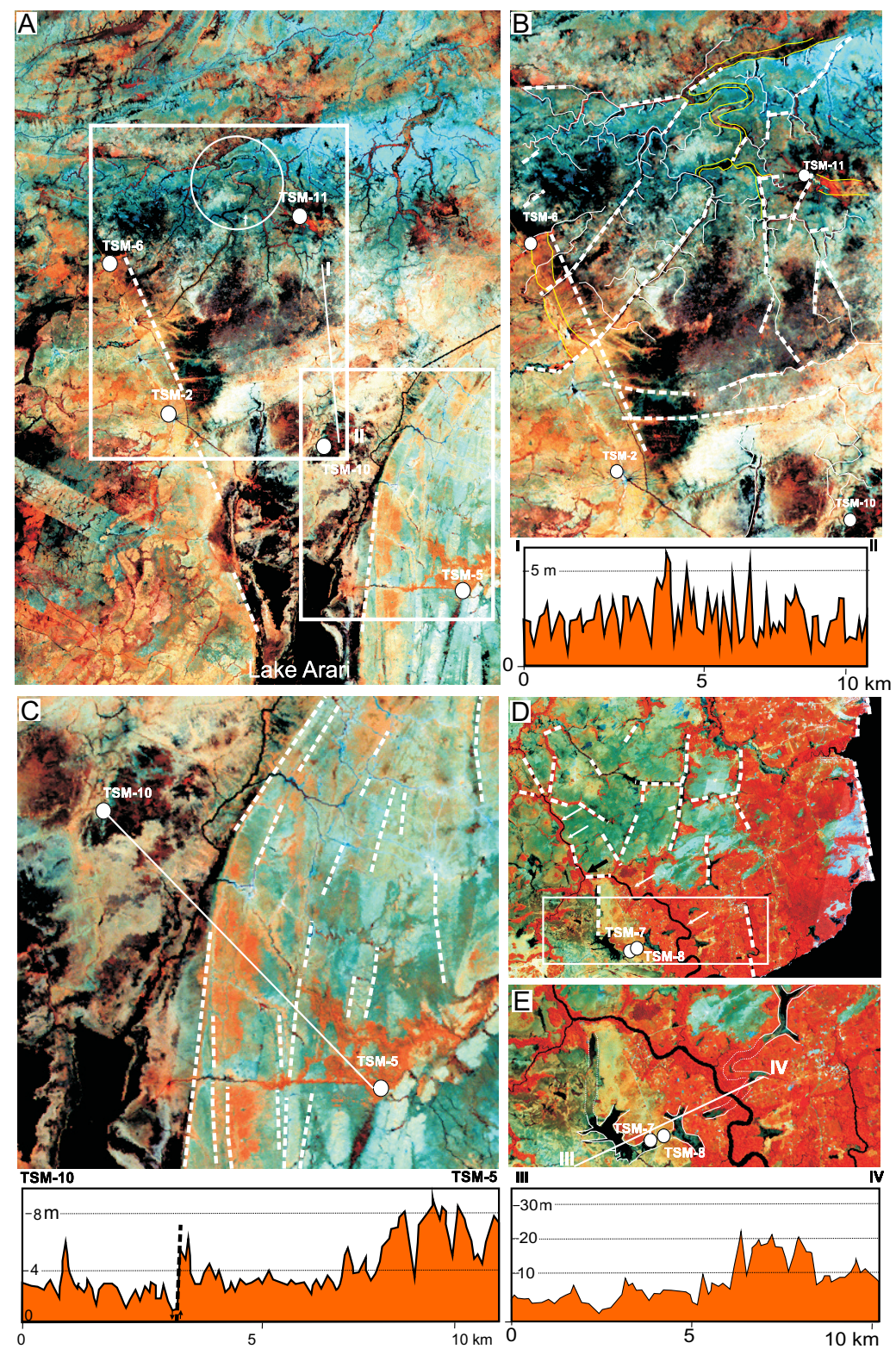

Fig. 4 - Landsat images, composition $=4(\mathrm{R}), 5(\mathrm{G}), 7(\mathrm{~B})$, illustrating areas between drills, where drainage lineaments are related to tectonic activity. A) Location of drills TSM-2, TSM-5, TSM-6, TSM-10 and TSM-11 at the mouth of the large Arari paleoestuary to the north of Lake Arari. Note that both margins of this paleoestuary is highlighted by straight lineaments (the upper and lower inside boxes locate figures B and C, respectively). B) Detail of figure A, illustrating several straight drainage lineaments between the drills TSM-6 and TSM-11, and between TSM-11 and TSM-10. C) Detail of figure A, illustrating the area between the drills TSM-10 and TSM-5, located in the western, straight margin of the paleo-estuary. Note the several NNE-SSW oriented lineaments defined by straight channels and sand bars that parallel the paleoestuary margin. D) Area nearby the drills TSM-7 and TSM-8, which contains several straight lineaments related to faults. Note a main channel (white arrows) that is meandering to the southeast and becomes straight to the northwest after a subtle inflexion at high angle (black arrow). The inside box locates figure E. E) A detail of figure D, illustrating several elongated lakes that can be connected to form a paleochannel. The topographic profiles I-II, TSM-10-TSM-5, and III-IV in the lower portions of figures B, C and E, respectively, illustrate digital elevation gradients obtained from SRTM data. The several white hatched lines in all figures indicate morphostructural lineaments suggestive of tectonics. Red colors highlight areas dominated by trees; green, light blue and light yellowish colors indicate grasslands; black and dark blue colors indicate water. See text for further explanations. 
of the estuary margin boundary, respectively (see the topographic profile in the lower part of Fig. 4C). In addition, the area located to the east of the estuary is dominated by a series of NNE-SSW straight sand bars that parallel the estuary margin. These were related to the westward migration of the estuarine channel (Rossetti et al. 2007). Although main water courses in this area flow northwestward, crossing over the sand bars, some channels parallel these sand ridges, configuring an angular drainage pattern. The last area to be described is the one around the drills TSM-8 and TSM-9. These drills are located near the western margin of Marajó Island (Fig. 4D), in a place that marks a sharp boundary between dense forest over Miocene strata to the west, and savanna over Quaternary deposits to the east. The modern drainage, particularly to the north of the drills, is arranged in an angular to rectangular pattern.

Another remarkable feature in this area is the occurrence of several elongated lakes that are aligned resembling sinuous channels (Fig. 4E). Interestingly is that these lakes show continuity with paleochannel segments. This situation reveals that the lakes are most likely primarily part of a channel system in process of abandonment. Noteworthy is the presence of a NWSE oriented modern channel to the west of the drills, which varies rapidly from meandering to straight, with the change in pattern taking place at high angles right at the boundary between forest and savanna (Fig. 4E). This contact is marked by a digital topographic gradient up to $15 \mathrm{~m}$ (see the topographic profile in the lower part of Figure 4E), which results from the combined effect of vegetation and a true topographic difference, as verified during fieldwork.

\section{DISCUSSION}

Both the spatial distribution of the sedimentary units and the morphostructural features described herein are consistent with the interpreted geological section provided for the study area. Tectonic faults were added in order to accommodate the differences in age and in bed thickness among the investigated drills. An alternative interpretation that could also explain the observed differences in age and bed thickness was disregarded herein, based on the following lines of evidence:
1) there is a significant variation in the thickness of the stratigraphic units when all drills are compared, with correlatable beds displaying offsets larger than $30 \mathrm{~m}$;

2) the changes in thickness of the stratigraphic units are not random, but instead they follow a regular pattern of simultaneous increment with respect to the suggested depressed areas;

3) there is a subtle change in unit thickness at some places, with all units being much thicker in drill SM-1;

4) strata recording comparable radiocarbon ages are vertically displaced up to $100 \mathrm{~m}$ depth, as occurs with deposits at the bases of the drills SM-1 and TSM-4. This attests the presence of areas with high accommodation rates, in contrast to adjacent areas where sediment accumulation took place relatively at a slower pace; and

5) there is an overall upward reduction in the thickness of the sedimentary units, which suggests that the youngest unit was deposited when accommodation space was reduced with respect to the older units.

The foregoing highlighted characteristics of the sedimentary units in the study area are easier to be accommodated within a tectonic model, as the one suggested in Figure 3. It is important to mention that the several interpreted faults depicted in this figure remain to be demonstrated in the field with basis on a larger volume of data, particularly regarding sub-surface information such as shallow seismic. Unfortunately, these data are not available yet in order to test this model. However, previous studies have documented that eastern Marajó Island displays many morphostructural lineaments (R.L. Bemerguy, unpublished data, Rossetti et al. 2008a) that can be related to main tectonic trends recognized in other Amazonian areas (e.g., Igreja 1992, Costa et al. 1993, 1995, 2002, Costa and Hasui 1997, Bemerguy et al. 2002, Almeida-Filho and Miranda 2007). According to these authors, these lineaments result from reactivation of old normal and transform fault zones, a process that took place during the Tertiary, but remained 
in effect up to the Holocene (Costa et al. 1996, 1997, 2001, Bezerra 2003, Silva 2005).

The morphostructural characterization provided herein is consistent with the presence of faults among the studied drills in eastern Marajó. Tectonic influence is suggested by several features, mostly including: abundance of straight channels that are either connected at high angles or are distributed parallel to each other; locally meandering channels that give rise to straight channels; rapid change from large to narrow channels; dominance of drainage organized into an angular, rectangular or parallel pattern; and presence of segments of paleochannels with sharply based edges, defined by the interception of straight modern channels. All these features are regarded as highly suggestive of tectonic influence during the development of drainage systems (Howard 1967, Ouchi 1985, Summerfield 1993).

The area between the drills TSM-11 and TSM-6 displays a set of NE-SW oriented, straight channels that are highly suggestive of major faults. It is interesting to notice that the drill TSM-6, located at the western margin of the paleoestuary, shows stratigraphic units that are positioned at shallower depths with respect to correlatable strata from drill TSM-11, this located in the center part of the paleoestuary. This situation is consistent with SW-dipping fault planes, as depicted in Figure 3. The two ENE-WSW oriented channels located in an area with slightly higher topography between the drills TSM11 and TSM-10 are also attributed to the influence of faults. This is proposed with basis on their straight course, the parallel arrangement to each other, and the anomalous orientation separating northward and southward flowing channels.

\section{FINAL REMARK}

The stratigraphic framework proposed herein for the sedimentary succession in eastern Marajó Island indicates that tectonics related to fault reactivation was an important process to preserve the late Quaternary sedimentary units. Without the influence of this factor, sediment preservation on this low-lying terrain would have been negligible, even considering the influence of global eustatic rises. The sedimentary pile accumulated as a function of fault displacement in this area serves as an important information source for reconstructing the effect of Quaternary events in low-lying Amazonian areas.

The increasing documentation of Quaternary tectonics in Amazonia motivates to look for other areas similar to Marajó Island, where fault displacement creates enough space to accommodate significant sedimentation. This can provide information for reconstructing the effect of Quaternary events in Northern Brazil.

\section{ACKNOWLEDGMENTS}

This work was funded by Fundação de Amparo à Pesquisa do Estado de São Paulo (FAPESP - Project \# 004/ 15518-6), and it had the logistic contribution of the Museu Paraense Emílio Goeldi.

\section{RESUMO}

A visão tradicional de que a Amazônia brasileira localiza-se em uma área tectonicamente estável desde o Cretáceo está mudando perante a crescente documentação de reativações de falha, até mesmo durante o Holoceno. Como o registro sedimentar respondeu a esses eventos é um tema que permanece por ser abordado com base em dados de campo. Este trabalho enfatiza a correlação estratigráfica de depósitos quaternários tardios no leste da Ilha do Marajó, com o objetivo de demonstrar a importância de reativações de falha na origem e preservação desses depósitos. Apesar da localização em área de plataforma de uma margem continental passiva, três unidades estratigráficas estudadas mostram significantes rejeitos verticais, que definem dois depocentros, explicados por deslocamentos tectônicos. Esta interpretação é reforçada por várias feições morfoestruturais relacionadas com falhas localizadas entre os poços estudados. Sem influência tectônica, a preservação de sedimentos nesse terreno, caracteristicamente plano, seria imperceptível. Os resultados do presente trabalho motivam a procurar outras áreas tectonicamente influenciadas da Amazônia, que possam ter atuado como sítios de acomodação de sedimentos durante o Quaternário tardio. Esses registros sedimentares têm grande potencial de serem fontes de informações valiosas para auxiliar na reconstrução de eventos geológicos quaternários no norte do Brasil.

Palavras-chave: Amazônia, tectônica, Quaternário, arcabouço estratigráfico, datação radiocarbono, sedimentação. 


\section{REFERENCES}

Azevedo RP. 1991. Tectonic evolution of Brazilian Equatorial Continental Margin Basins. PhD Thesis, University of London, London.

Almeida-Filho R And Miranda FP. 2007. Mega capture of the Rio Negro and formation of the Anavilhanas Archipelago, Central Amazonia, Brazil: evidences in an SRTM digital elevation model. Rem Sens Envir 110: 387-392.

Bemerguy RL, Costa JBS, Hasui Y, Borges MS And SOARES JR AV. 2002. Structural geomorphology of the Brazilian Amazon region. In: KLeIN EL, VAsques ML AND Rosa Costa LT (Eds), Contribuições à Geologia da Amazônia: SBG-Núcleo Norte, Belém, PA, p. 245-258.

BEZERrA PEL. 2003. Compartimentação morfotectônica do interflúvio Solimões-Negro. $\mathrm{PhD}$ Thesis, Universidade Federal do Pará, Belém, PA.

COSTA JBS AND Hasui Y. 1997. Evolução geológica da Amazônia. In: Costa ML AND ANGÉlicA RS (Eds), Contribuições à Geologia da Amazônia: SBG, Belém, PA, p. 15-19.

Costa JBS, Borges MS, Bemerguy RL, Fernandes JMG, Costa JR And Costa ML. 1993. A evolução cenozóica da região de Salinópolis, nordeste do Estado do Pará. Geociências 12: 373-396.

Costa JBS, Hasui Y, Borges MS ANd Bemerguy RL. 1995. Arcabouço tectônico mesozóico-cenozóico da região da calha do Amazonas. Geociências 14: 77-83.

Costa JBS, Bermeguy RL, Hasui Y, Borges MS, FerREIRA JR CRP, BEZERRA PEL, COSTA ML AND FERNANDES JMG. 1996. Neotectônica da região amazônicaaspectos tectônicos, geomorfológicos e deposicionais. Geonomos 4: 23-44.

Costa JBS, Bemerguy RL, Hasui Y AND Borges MS. 2001. Tectonics and paleogeography along the Amazon River. J South Am Earth Sci 14: 335-347.

Costa Ml, Moraes EL, Behling H, Melo JCV, SiqueIRA NVM AND KERN DC. 1997. Os sedimentos de fundo da Baía de Caxiuanã. In: LISBOA PLB (Ed), Caxiuanã: Populações Tradicionais, Meio Físico e Diversidade Biológica: Mus Par Em Goeldi, Belém, PA, p. 121-137.

Costa ML, Kern DC, Behling H and Borges M. 2002. Geologia. In: LisboA PLB (Ed), Caxiuanã: Populações Tradicionais, Meio Físico e Diversidade Biológica: Mus Par Em Goeldi, Belém, PA, p. 179-206.
HowARD AD. 1967. Drainage analysis in geologic interpretation: A summation. Am Assoc Petrol Geol Bull 51: 2246-2259.

IgReJA HLS. 1992. Aspectos Tectono-sedimentares do Fanerozóico do Nordeste do Estado do Pará e Noroeste do Maranhão. Doctoral Thesis, Universidade Federal do Pará, Belém, PA.

McCormac FG, Hogg AG, Blackwell PG, Buck CE, Higham TFG AND Reimer PJ. 2004. Southern Hemisphere Calibration, 0-11.0 Cal kyr BP. Radiocarbon 46: 1087-1092.

Miotto JA. 1993. Sismicidade e zonas sismogênicas do Brasil. Doctoral Thesis. Universidade Estadual Paulista, Rio Claro, SP.

OUCHI S. 1985. Response of alluvial rivers to slow active tectonic movement. Geol Soc Am Bull 96: 504-515.

Rossetti DF AND VALERIANo MM. 2007. Evolution of the lowest Amazon basin modeled from the integration of geological and SRTM topographic data. Catena 70: 253-265.

Rossetti DF, VAleriano MM ANd Thalles M. 2007. An abandoned estuary within Marajó Island: implications for Late Quaternary paleogeography of Northern Brazil. Est and Coasts 30: 813-826.

Rossetti DF, Góes AM, VAleriano MM And MiranDA MCC. 2008a. Quaternary tectonics in a passive margin: Marajó Island, Northern Brazil. J Quat Sci 23: 121-135.

Rossetti DF, Valeriano MM, Góes AM and Thalles M. 2008b. Paleodrainage in Marajó Island (Northern Brazil) and its relation to Holocene relative sea-level. The Holocene 18: 923-934.

Silva CL. 2005. Análise da tectônica Cenozóica da região de Manaus e adjacências. Doctoral Thesis, Universidade Federal do Amazonas, Manaus, AM.

SUMMERFIELD MA. 1993. Global geomorphology: an introduction to the study of landforms. Logman Scientific \& Technical, New York, USA.

SzATMARi P, Fraçolin JBL, ZanotTo O AND WolfF S. 1987. Evolução tectônica da margem equatorial brasileira. Rev Bras Geoc 17: 180-188.

Talma AS AND Vogel JC. 1993. A simplified approach to calibrating C14 dates. Radiocarbon 35: 317-322. 